\title{
Ultrastructural Analysis of Kidney, Liver and Duodenum Isolated from Treated Rats with Ginkgo Biloba Extract and Effects of this Medicinal Plant on the Biodistribution of the Radiopharmaceutical Sodium Pertechnetate
}

\author{
Silvana Ramos Farias Moreno ${ }^{1,2^{*}}$, Jorge José de Carvalho ${ }^{3}$, Ana Lúcia Nascimento ${ }^{3}$, \\ Adriano Arnobio ${ }^{1}$, Beni Olej $^{1}$, Margareth de Oliveira Timóteo ${ }^{1}$, Luiz Querino de Araújo \\ Caldas $^{1}$ and Mário Bernardo Filho ${ }^{2}$ \\ ${ }^{I^{*}}$ Universidade Federal Fluminense; Marquês de Paraná, 303; 24030-210; srfmoreno@hotmail.com; Niterói - RJ - \\ Brasil. ${ }^{2}$ Departamento de Biofísica e Biometria; Instituto de Biologia Roberto de Alcântara Gomes, Universidade \\ do Estado do Rio de Janeiro, Av. 28 de Setembro, 87; 20551030, Rio de Janeiro - RJ - Brasil. ${ }^{3}$ Departamento de \\ Histologia e Embriologia; Instituto de Biologia Roberto de Alcântara Gomes, Universidade do Estado do Rio de \\ Janeiro, Av. 28 de Setembro, 87; 20551030, Rio de Janeiro - RJ - Brasil.
}

\begin{abstract}
Ginkgo biloba extract (EGb) has been used to treat memory and concentration deficits, acts as platelet activating factor antagonism and prevents against damages caused by free radicals. EGb is a standardized extract that contains 24\% flavonoids and 6\% terpenoids. The aim of this work was to evaluate the possible influence of an EGb on the ultrastructure of some organs isolated from rats and on the biodistribution of sodium pertechnetate $\left({ }^{99 m} \mathrm{TcO}_{4} \mathrm{Na}\right)$. The animals were treated with EGb and after six days, received ${ }^{99 m}{ }^{\mathrm{TcO}} \mathrm{H}_{4} \mathrm{Na}$. The organs were isolated and fixed for ultrastructural analysis. The results showed that EGb has modified the ultrastructure of kidney, liver and duodenum and altered the biodistribution of ${ }^{99 m} \mathrm{TCO}_{4} \mathrm{Na}(\mathrm{P}<0.05)$. It is speculated that the substances present in the EGb could act directly or generate metabolites capable to promote changes on the biodistribution of

${ }^{99 m} \mathrm{Tc}_{4} \mathrm{Na}$ and on the morphology of organs at ultrastructural level.
\end{abstract}

Keywords: Ginkgo biloba, technetium-99m, biodistribution, morphology, ultrastructure

\section{INTRODUCTION}

The utilization of herbal products has increased over the past several years and the accurate knowledge of their toxic effects is limited (Hansten and Horn, 1991; Rotblatt et al., 2002; Simões et al., 2007). Sometimes, the possible toxicity and the drug interaction of these products are not yet completely known (Hansten and Horn, 1991; Rotblatt et al., 2002; Simões et al., 2007).

Ginkgo leaves contain a complex mixture of a number of biologically active molecules including flavonoids, terpenoids, steroids, organic acids, alkanes and alkenes, sugars, polyphenols, cytokine, lectin and carotenoids (Simões et al., 2007). The majority of the researches on the

\footnotetext{
Author for correspondence
} 
effects of ginkgo have been done using a standardized Ginkgo biloba leaf extract called EGb 761 (Germany). EGb 761 is standardized to contain $24 \%$ flavones glycosides and $6 \%$ terpene lactones, but this preparation also contains a variety of other constituents including organic acids and sugars. This extract has several effects, including: [a] increases the blood flow, [b] acts as platelet activating factor antagonism, [c] prevents the membrane against the damages caused by free radicals and [d] treats the memory and concentration deficits (Pietta, 1999; Rotblatt et al., 2002; Simões et al., 2007).

The histological study of the kidney, liver and intestines has been an important resource for investigation of the metabolism of pharmaceuticals (Amdur, 2001). The renal cortex is the bigger part of the kidney and consequently it receives important nutrition from blood (Amdur et al., 2001). In the renal cortex, there are numerous tubules and glomerulus. Glomerular lesions may be revealed by the presence of alterations in the density and number of cytoplasm structures, such as, mitochondrias, Golgi complex and endoplasmic reticule. There is the possibility of nefrotoxicants to act directly in the glomerulus causing alteration on the filtration or on the tubular function (Amdur et al., 2001).

Hepatocytes contain numerous mitochondria, ribosome and endoplasmic reticule. During the metabolization of xenobiotics, hepatic cells can produce substances with lesive potential, including the morphological alterations (Amdur et al., 2001). Cytoplasm vacuoles normally, can be present in the hepatocytes which inadequately received toxic substances (Amdur et al., 2001). The intestinal epithelium has several absorptive and caliciform cells. The presence of an alteration in the organelles of these cells, such as mitochondria, endoplasmic reticules and Golgi complex, may be consequence of exogenous stimulus (as, drugs for example) (Amdur et al., 2001).

Nascimento et al. (2001) have demonstrated that metabolites isolated from isoflavonols, such as, the toxin T-2, could be responsible by the lesive effect observed in the condrocytes and vascular tissue of animals treated with soy extract (Nascimento et al., 2001). Simões et al. (2007) have described that the flavonoids would be capable to influence some biological processes, including the mutagenic activity (Simões et al., 2007). Veiga-Júnior et al. (2005) have reported lesions in the liver of animals treated with terpenoids (Veiga-Júnior et al., 2005) and Simões et al. (2007) have associated the toxicity effect of natural drugs with the presence of sesquiterpenes and diterpenes.

Radiobiocomplexes may be prepared with technetium-99m (Tc-99m), as sodium pertechenetate $\left({ }^{99 \mathrm{~m}} \mathrm{TcO}_{4} \mathrm{Na}\right)$, and used as imaging agents (Hladik III et al., 1987; Saha, 2004). The bioavailability of radiobiocomplexes can be recognizably altered by a wide variety of conditions, such as, drug therapy, radiation therapy, diseases and medicinal plant therapy (Hesslewood and Leung, 1994; Oliveira et al., 2003; Bernardo-Filho et al., 2005; Moreno et al., 2007a; Moreno et al., 2007b).

As the investigation of herbs interaction with cells is highly relevant and necessary, and also there are studies suggesting the association of some constituents of Ginkgo biloba (EGb) with possible toxic effects, the purpose of this work was: (i) to evaluate the influence of a Ginkgo biloba extract (EGb 761) on the ultrastructure (electronic microscopy) of some organs isolated from Wistar rats treated with this extract and (ii) to assess the effect of this extract on the biodistribution of the sodium pertechnetate.

\section{MATERIAL AND METHODS}

Commercial solution Ginkgo biloba extract (EGb 761, China Jiangsu Medicines and Health Products Lot GB 001128, w/w, Galena, RJ Brazil) containing $24 \%$ of flavonoids was prepared in the $0.9 \% \mathrm{NaCl}$ (saline solution). From this solution (crude extract), saline preparations containing 400 $\mathrm{mg} / \mathrm{mL}(1526 \mathrm{mg} / \mathrm{kg})$ of the commercial extract were done. These preparations were administrated $(1 \mathrm{~mL})$ to female Wistar rats (with 3 months age, weight of $262 \pm 15$ gram, $n=5$ ) during 6 days (intragastric via). The control group has received 1 $\mathrm{mL}$ of a solution of $0.9 \% \mathrm{NaCl}$.

After that, $0.3 \mathrm{~mL}$ of a Tc-99m solution, as sodium pertechnetate $(3.7 \mathrm{MBq})$ recently milked from a Molibdenium-99/Technetium-99m generator (Instituto de Pesquisas Energéticas e Nucleares, Comissão Nacional de Energia Nuclear, São Paulo, Brazil) was injected by ocular plexus. The animals were rapidly sacrificed (after 10 minutes) following the criteria of the Ethical Committee of the Institution. The organs were isolated (brain, liver, duodenum, heart, kidney, stomach, pancreas, lung, blood, bone and thyroid) and the 
radioactivity was determined. The percentages of radioactivity per gram of each organ (\%ATI/gram) were calculated. A statistical analysis of the results (ANOVA test, with Dunnet test, $\mathrm{p}<0.05$ ) was performed.

Histological preparations were carried out with pieces $(n=5)$ of liver, kidney and duodenum isolated from the animals that have received EGb $(1526 \mathrm{mg} / \mathrm{kg})$ per intragastric via. These pieces of the organs (treated and control) were fixed in $2.5 \%$ glutaraldehyde (Riedel-de-Haen) and $0.1 \mathrm{M}$ cacodylate buffer ( $\mathrm{pH}$ 7.2). The fixative was added with either $0.25 \%$ tannic acid. The post fixation was with $1 \%$ osmium tethroxide (Sigma, USA), $0.8 \%$ potassium ferricyanide and $5 \mathrm{mM}$ calcium chloride $\left(\mathrm{CaCl}_{2}\right)$ in $0.1 \mathrm{M}$ cacodylate buffer. The tissues were dehydrated in acetone and embedded in Epon (Embed-812). Thin sections $(60 \mu \mathrm{m})$ were retreated from a copper grating (300 Mesh). The samples received uranil acetate (5\%) during 60 minutes, and washed with distilled water. After that, the tissues were dried in the filter paper and washed again with lead cristate. The observation was carried out by electronic microscopy of transmission. (ZEISS EM 906 Model, Germany). Images of these tissues were recorded on a computer employing Nero Pro plus Image Program using the increase of $600 \mathrm{X}, 7750 \mathrm{X}$ and 10000X (Bar $20 \mu \mathrm{m}$ and 50 $\mu \mathrm{m})$.

\section{RESULTS}

The results about the effect of the EGb on the biodistribution of the sodium pertechnetate have shown a significant $(p<0.05)$ decrease of the uptake of the studied radiobiocomplex in the duodenum after the treatment with EGb (from $1.0 \pm 0.3$ to $0.5 \pm 0.3$ ) and this reduction was significant $(\mathrm{p}<0.05)$.

The results about the effect of the Ginkgo biloba on the ultrastructure of organs are indicated in the figure $1(\mathrm{~A}$ and $\mathrm{B})$, in the figure $2(\mathrm{~A}$ and $\mathrm{B})$ and in the figure 3 ( $\mathrm{A}$ and $\mathrm{B})$.

The figure 1A shows an electronic micrograph of the kidney isolated from animal controls, which presents the glomerular basal lamina with normal aspect. The comparison with the figure 1B (treated animals) indicates that the glomerular basal lamina of treated animals is increased (Figure 1B).
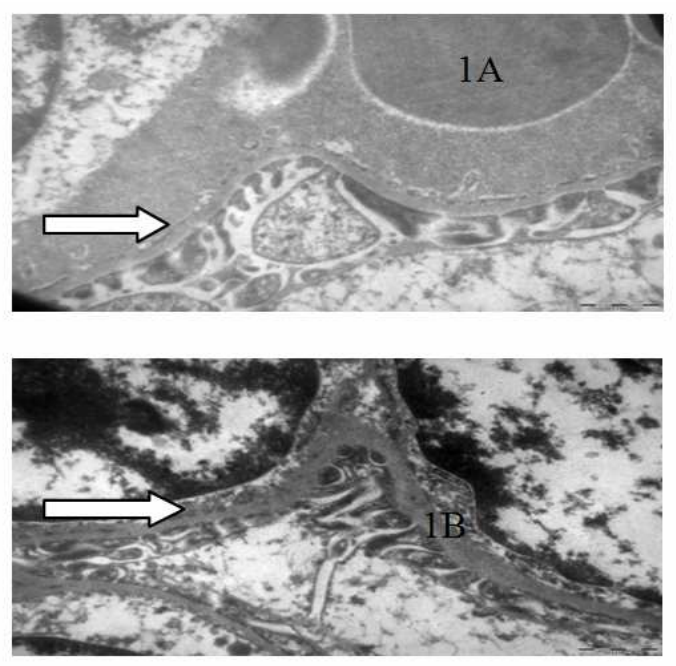

Figure 1 - Electronic micrograph of kidney. 1A: In the control animals, glomerular basal lamina with normal aspect (white arrow). 1B: In the treated animals, glomerulus with increased basal lamina (white arrow). Bar: $20 \mu \mathrm{m}$.

The figure 2A shows an electronic micrograph of liver (control animals). The mitochondrias (inside hepatocytes) are well developed. It was also observed the normal presence of numerous endoplasmic reticules. In the treated animals (figure 2B), it may be seen a reduction in the number of the endoplasmic reticule and they show a reduced volume. 

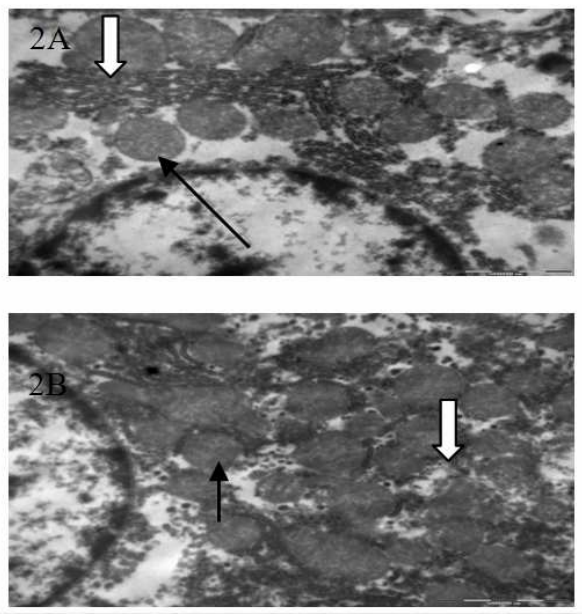

Figure 2 - Electronic micrograph of liver. 2A: In the control animals, presence of numerous cisterns of the granular endoplasmic reticule (white arrow) and mitochondrias well developed (black arrow). 2B: In the treated animals, there is a reduced number of cisterns of the granular endoplasmic reticule (white arrow) and mitochondrias (black arrow). Bar: $50 \mu \mathrm{m}$.

On the figures $3 \mathrm{~A}$ and $3 \mathrm{~B}$ are the images of the duodenum isolated from control and treated animals, respectively. In the control animals, the mitochondrias and microvillus are well developed and they present normal aspect (figure $3 \mathrm{~A}$ ). In the treated animals, it may be seen the presence of a reduced number of mitochondrias. Moreover, there are fragmentations in the endoplasmic reticule. It also may be seen that the polyribosomes are dispersed, the mitochondrial crists are reduced and it was observed the inadequate presence of vacuole inside this cytoplasm organelle.

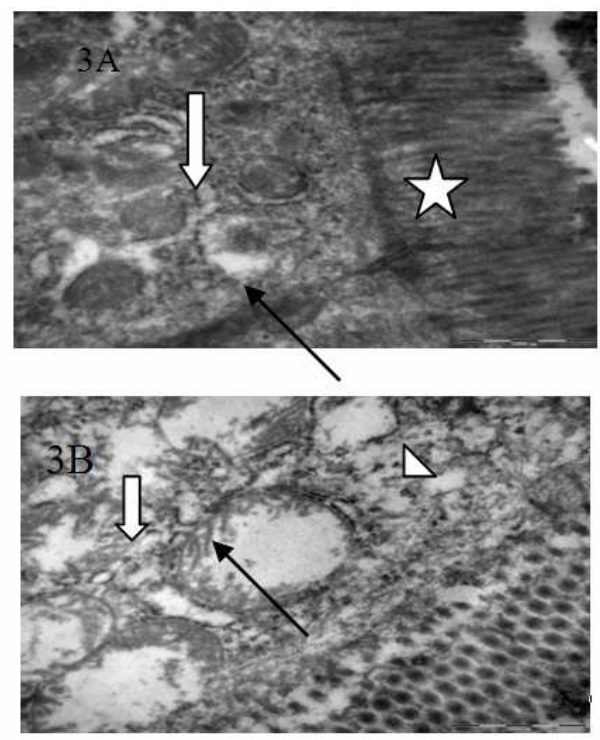

Figure 3 - Electronic micrograph of duodenum. 3A: In the control animals, presence of cisterns of the granular endoplasmic reticule (white arrow), microvillus (star) and mitochondrias (black arrow) with normal aspect. 3B: In the treated animals, it is observed that there is a reduced number of cisterns of the endoplasmic reticule (white arrow), the mitochondrias present vacuole, crests decreased (black arrow) and polyribosomes disperse (head of arrow). Bar: $50 \mu \mathrm{m}$. 


\section{DISCUSSION}

Significant morphometry alterations (light microscopy) $(\mathrm{p}<0.05)$ on kidney, liver and duodenum consequence from treatment with EGb were already found in our previous studies (Moreno et al., 2007c). These findings and the uptake of sodium pertechnetate altered in the duodenum from animals treated with EGb could justify the present study at ultrastructural level (Figures 1, 2 and 3).

Several important biological effects have been associated with the use of Ginkgo biloba, and Rotblatt et al. (2002) have reported the presence of active substances (flavonoids, diterpenes and terpenes) in the EGb. Nascimento et al., (2001) have demonstrated that metabolites from isoflavonols, such as, the toxin T-2, could be responsible by the lesive effect observed in the condrocytes and in the vascular tissue of animals treated with soy extract (Nascimento et al., 2001). Simões et al., (2007) have described that the flavonoids would be capable to influence some biological processes, including the mutagenic activity (Amdur et al., 2001; Simões et al., 2007). These reports and our findings may suggest an inductive potential of oxidative stress that could be associated with flavonoids present in the EGb.

Terpstra et al. (2000), have used coffee oil terpenes to evaluate cholesterol levels in plasma of rats and they observed hypercholesterolemical effects in these animals (Terpstra et al., 2000). Veiga-Júnior et al. (2005) have reported lesions on the liver of animals submitted to the treatment with terpenes obtained from some natural drugs. Moreover, these toxicological studies have demonstrated that diterpenes may lead the hepatocytes of rats to the apoptosis until 2 hours after in vitro treatment (Veiga-Júnior et al., 2005). These authors have also discussed that the toxicity action in the kidney may be due to the presence of terpenes (Veiga-Júnior et al., 2005). These reports may suggest that EGb also could have a potential of toxicity in the liver associated with the presence of terpenoids (Figure 2).

The findings observed in this work about the effect of the EGb have revealed important changes on the ultrastructure of kidney after treatment with this herb. There is the possibility that nefrotoxicants act directly on the glomerular filtration or on the tubular function (Amdur et al., 2001). It is possible to speculate that the presence of active metabolites from $\mathrm{EGb}$ may induce an increase of the glomerular basal lamina and consequently it should promote an increase of the glomerular function, as a protection mechanism of the glomerulus (figure 1B), as previously suggested (Amdur et al., 2001; Simões et al., 2007; Moreno et al., 2007c). Therefore, the metabolization and the possible presence of free radicals in the liver, could justify the reduction of the endoplasmic reticule of hepatocytes observed in the present study (figure 2B) (Veiga-Júnior et al., 2005).

Moreno et al., 2007c have already showed morphological changes (light microscopy) on the cellular surface of the duodenum in rats treated with EGb. In the recent report, as the caliciform cells (light microscopy) of the treated animals were poorly visible (Moreno et al., 2007c), the presence of (i) a reduced number of mitochondrias, (ii) of vacuole (no waited) in this organelle, and (iii) the fragmentation of the endoplasmic reticule (figure 3B, few cisterns) in the animals treated, would reinforce the hypothesis of the lesive action of metabolites of EGb (Moreno et al., 2007c). It is possible to suggest that the in vivo treatment with $\mathrm{EGb}$ may generate active metabolites that should alter the ultrastructure of cells and the biodistribution of the sodium pertechnetate.

In conclusion, the analysis of the results described in this work, indicated that the alterations found, probably, were due to the effect of the in vivo treatment with $\mathrm{EGb}$ extract.

\section{ACKNOWLEDGEMENTS}

The present work was carried out with support of the CAPES, CNPq, UERJ and UFF. The authors are also grateful to Michael G. Stabin, PhD, CHP, Department of Radiology and Radiological Sciences, Vanderbilt University, Nashville, for revisions to the English grammar in the paper.

\section{RESUMO}

O extrato de Ginkgo Biloba extract (EGb) tem sido usado para tratar dificuldades de concentração, memória, age como antagonista do fator de ativação de plaquetas e previne contra danos causados por radicais livres. EGb é um extrato padronizado com $24 \%$ de flavonóides e $6 \%$ de 
lactonas terpênicas. O objetivo deste estudo foi avaliar o efeito de um EGb na ultraestrutura de alguns órgãos isolados de ratos e na biodistribuição do radiofármaco pertecnetato de sódio $\left({ }^{99 \mathrm{~m}} \mathrm{TcO}_{4} \mathrm{Na}\right)$. Os animais foram tratados com $\mathrm{EGb}$ e após 6 dias receberam ${ }^{99 \mathrm{~m}} \mathrm{TcO}_{4} \mathrm{Na}$. Os órgãos foram isolados e a radioatividade determinada. Os tecidos foram fixados para microscopia eletrônica. Os resultados mostraram que EGb alterou a ultraestrutura do rim, figado e duodeno e modificou a biodistribuição do ${ }^{99 \mathrm{~m}} \mathrm{TcO}_{4} \mathrm{Na}$. Sugerimos que substâncias presentes no EGb poderiam agir diretamente ou gerar metabólitos capazes de promover alterações na biodistribuição e na morfologia de órgãos em nível ultraestrutural.

\section{REFERENCES}

Amdur, M. O.; Doull, J.; Klassen, C. D. (2001), Casarett and Doull's, Toxicology: The Basis Science of Poisons. $6^{\mathrm{a}}$ Edition. New York. In Macmillan Publishing.

Bernardo-Filho, M.; Santos-Filho, S. D.; Moura, E. G.; Penas, M. E.; Cardoso, V. N.; Brito, L.C., (2005), Drug interaction with radiopharmaceutical: a Review. Braz. Arch. Biol. Technol., 48, 13-27.

Hansten, P. D. and Horn J.R. (1991), Drug Interactions. Lea and Philadelphia. Hesslewood, S. and Leung, E., 1994. Drug interactions with radiopharmaceuticals. Eur. J. Nucl. Med., 21, 348356.

Hesslewood, S.; Leung, E. (1994), Drug interactions with radiopharmaceuticals. Eur. J. Nuc. Med. 21, 348-356.

Hladik III, W. B; Saha, G. B.; Study, K. T. (1987), Therapeutic Applications of Radiopharmaceuticals. Essentials of Nuclear Medicine Science, London. Willians and Wilkins.

Moreno, S. R. F.; Carvalho, J. J.; Olej, B.; BernardoFilho, M.; Caldas, L. Q. (2007a), The ingestion of a
Nectandra membranacea extract changes the bioavailability of $\mathrm{Tc}-99 \mathrm{~m}$ radiobiocomplex in rat organs. Biol. Res. 40, 131-135.

Moreno, S. R. F.; Carvalho J. J.; Olej, B.; BernardoFilho, M.; Caldas, L. Q. (2007b), Effect of oral ingestion of an extract of the herb Uncaria tomentosa on the biodistribution of sodium pertechnetate in rats. Braz. J. Med. Biol. Res. Biol. 40, 77-80.

Moreno, S. R. F.; Carvalho, J. J.; Nascimento, A. L.; Pereira, M.; Rocha, E. K.; Olej, B, Caldas, L. Q. A.; Bernardo-Filho, M. (2007c), Qualitative and quantiative analysis of kidney, liver and duodenum isolated from treated rats. Food Chem. Toxicol., 45,19-23.

Nascimento, J. A. F. B.; Nunes, V. A.; Guedes, R. M. C. (2001), Toxina T-2 e alterações do crescimento endocondral em frangos de corte. Braz. Arch. Zoot., $\mathbf{5 3}, 1-15$.

Oliveira, J. F.; Oliveira, M. B.; Braga, A. C. S.; Jales, R. L. C.; Bernardo-Filho, M. (2003), Assessment of the effect of Fucus vesiculosus extract on the labeling of blood constituents with Tc-99m and the histological modifications on the shape of the red blood cells. Food Chem. Toxicol., 41, 15-20.

Pietta, P.G. (1999). Flavonoids as Antioxidants. J Nat Prod., 63, 1035-1042.

Rotblat, M.; Ziment, I.,(2002), Evidence-Based Herbal Medicine. Philadelphia. Hanley and Belfus.

Saha, G.B. (2004), Fundamentals of Nuclear Pharmacy. Springer-Verlag. New York.

Simões, C. M.; Mentz, L.A.; Petrvick, P.R. (2007), Farmacognosia: Da planta ao medicamento. In Portuguese. Rio Grande do Sul. UFRGS/Edda/EFSC.

Trepstra, A.H. M; Katan, M. P. M. E.; Roos, B.; Beynen, A. C. (2000), The hypercholesterolemic effect of cafestol in coffee oil in gerbils and rats. $J$ Nutr Biochem., 11, 311-317.

Veiga-Junior, V. F. (2005), Medicinal Plants: Safe Cure? Quim Nova, 28, 519-528.

Received: August 12, 2008; Revised: September 02, 2008; Accepted: September 04, 2008. 